\title{
Rambles Along the Long Creek
}

\author{
By Hugh McLaughlin, Lewvan
}

The Estevan area has been much publicized for its mineral resources but I had an opportunity to see quite a different aspect of it when I lived beside the dam site on Long Creek for a year, and took long rambles. along the valley downstream from the dam.

Upstream from the dam site the valley was stripped bare of trees to prevent trash accumulating in the bottom of the newly-formed lake. In the last year or so, native shrubbery has grown up, including more than a dozen species-chokecherry, saskatoon, buffalo berry, etc.-and I have often thought that it would be nice to transfer some of it to other new dam sites such as the one at the Weyburn Hospital. It was satisfying to see the snow melt the first spring and a lake of some proportions form in the valley, to hear the buzz of motor boats and see the spray of water skiis, to enjoy frequent swims in the new lake, or to think of this water serving the power plant, and the fish and wildlife of the area. Still, it was the quiet valley below that I enjoyed the most.

It is an adventure to travel down a small stream in a canoe, with the next bend always beckoning on. The feeling is so different from the feeling one gets walking along the banks. I have travelled northern lakes and streams in a canoe, but they held no greater charm than going down Long Creek. Yes, the shores were lined with alder, birch and poplar along the Manigotagan in Manitoba, while the shadow of spruce fell on the water and great flats were covered with wild rice. But here huge elm, ash, and maple hang over the stream, and a great variety of shrubbery lines the valley. Fresh chips on the shore testify to the presence of beaver, then a beaver slide, and finally a beaver that lets you get quite close before slapping the water with its tail and diving. On the shore you see a deer and a fawn that you surprised by this unorthodox approach.
From the first crocus on the flats in spring, through the cactus and prairie lilies of July to the aster and sage brush in the fall; the seasons parade by. There are so many plants that I do not know in this area that I found it a bit frustrating rambling among them. Brick-red tops of hills were covered with evergreen creeping juniper. On the bare, eroded sides of some of the hills, in the dryness and the heat, another plant grew with twisted, tortured stems. With its sparse leaves, it did not catch one's eye until late fall when it really blossomed forth with yellow flowers not unlike the golden rod. I later learned that this plant is known by the rather prosaic name of rabbit brush.

Of all the memorable evenings spent lookıng and listening, one stands out above all. It was in September and the leaves were at their golden best. The red of saskatoon and chokecherry on the dry hillsides gave way to the reluctant yellow of elms and the rank greenness of grass near the water's edge. A beaver was calmly peeling the bark-from a willow twig not thirty feet away. After I had watched the beaver for some minutes, a snorting sound caused me to look up across a small field. The noise was caused by a pair if deer which jumped in and out of the trees fringing the creek almost like showoffs who had succeeded in attracting my attention. Then the evening colour of the skies began to fade. Three ycung fox hunted over the field, noses close to the ground, intent on mice and not on men. A skunk waddled over the cultivator ridges and a great horned owl swung out of the trees on silent wings. One heard the voices of birds of the evening. It was like a scene from a Walt Disney true-life movie-all within two or three miles of Estevan. May men use with wise stewardship the tangible resources of coal, oil and brick, but may they also preserve the intangible. May they learn to enjoy intimately the beauty of bird, flower and field, that succoured me during my stay by the valley. 